\title{
Modeling of Different Irrigation Methods for Maize Using AquaCrop Model: Case Study
}

\author{
Thamer Thamer ${ }^{1}$, Nadine Nassif ${ }^{2}$, Ayad Almaeini ${ }^{3}$, Nadhir Al-Ansari ${ }^{4}$, Diaa Hassan ${ }^{5}$ \\ ${ }^{1}$ Ecole Doctorale en Sciences et Technologie, Lebanese University, Rafic Hariri, Haddath, Lebanon \\ ${ }^{2}$ Faculty of Agronomy and Veterinary Sciences, Environment and Natural Resources Department, Lebanese University, \\ Dekwaneh, Beirut, Lebanon \\ ${ }^{3}$ College of Agricultural Engineering Sciences, Baghdad University, Baghdad, Iraq \\ ${ }^{4}$ Department of Civil, Environmental and Natural Resources Engineering, University of Technology, Lulea, Sweden \\ ${ }^{5}$ Water Resources Engineering College, Al-Qasim Green University, Babylon, Iraq \\ Email: alshibly.thamer@yahoo.com,nadinenassif3@hotmail.com,dr.ayad24@yahoo.com, *nadhir.alansari@ltu.se, \\ diaafliah@wrec.uoqasim.edu.iq
}

How to cite this paper: Thamer, T., Nassif, N., Almaeini, A., Al-Ansari, N. and Hassan, D. (2021) Modeling of Different Irrigation Methods for Maize Using AquaCrop Model: Case Study. Engineering, 13, 472-492. https://doi.org/10.4236/eng.2021.138034

Received: July 14, 2021

Accepted: August 23, 2021

Published: August 26, 2021

Copyright (c) 2021 by author(s) and Scientific Research Publishing Inc. This work is licensed under the Creative Commons Attribution International License (CC BY 4.0)

http://creativecommons.org/licenses/by/4.0/

\begin{abstract}
Modeling of irrigation methods is one of the most important techniques that contribute to the future of modern agriculture. This will conserve water as water scarcity is a major threat for agriculture. In this study, AquaCrop model was used to model different irrigation methods of maize in field trails in Al-Yousifya, $15 \mathrm{~km}$ Southwest of Baghdad. Field experiments were conducted for two seasons during 2016 and 2017 using five irrigation methods including furrow, surface drip and subsurface drip with three patterns of emitter depth $(10,20$ and $30 \mathrm{~cm})$ irrigation. AquaCrop simulations of biomass, grain yield, harvest index and water productivity were validated using different statistical parameters under the natural conditions obtained in the study area. For 2016 and 2017 seasons, results of $\mathrm{R}^{2}$ were 0.98 and $0.99,0.99$ and $0.99,0.99$ and 0.97 , and 0.8 and 0.73 for biomass, grain yield, harvest index and water productivity, respectively. The study has conducted that simulation using AquaCrop is considered very efficient tool for modeling of different irrigation applications for maize production under the existing conditions in the central region of Iraq.
\end{abstract}

\section{Keywords}

AquaCrop Model, Grain Yield, Maize, Subsurface Drip Irrigation, Water Productivity

\section{Introduction}

Agriculture faces a major challenge in the arid and semi-arid areas, which Iraq is 
due to the lack of irrigation water supplies as a result of climatic change and increased water demand for industrial and civil utilization [1]. Thus, food production will be effected either by the decrease in the areas currently cultivated or the inability to expand horizontally, to bridge the gap between the supply and demand for agricultural products [2].

Improving irrigation water management and increasing water use efficiency through prudent practices up to one drop is one of the best management irrigation techniques. Maize is the most important cereals planted in Iraq. The cultivated area of maize, in Iraq, for the last nine years reached around $(781,322)$ hectares, with a production amount of $(2,916,928)$ tons [3]. It's used for human and animals' consumption, especially poultry feeding. Maize is also one of crops most involved in several industrial products such as biofuels production [4] [5]. Maize is a summer crop that growth coincides with the hottest and driest months of the year in Iraq (July, August, and September) when it is completely lacks of precipitation [6]. Maize is a C4 crop that has high efficiency to produce much biomass rapidly with high water consumption compared to other crops. High yield of maize requires approximately 750 - $900 \mathrm{~mm}$ water per-season; this high-water requirement due to poor water management such as the use of the traditional irrigation methods will cause a massive waste in irrigation water and lower water use efficiency [7] [8] [9] [10]. Modern irrigation methods provide more water use efficiency through water in the root zone.

Moreover, good irrigation scheduling system could be achieved by the use of sprinkler, drip, and subsurface drip irrigation systems. Recent researches [11] [12]: Documented that required water for irrigation could be decreased by $35 \%$ $55 \%$ under the sprinkler or drip irrigation with high water use efficiency compared to traditional irrigation methods. Thus, efforts should always focus on improving water management to meet maximum yield with high water use efficiency, which is the main aim of irrigation management in arid and semi-arid regions [13]. The Food and Agriculture Organization (FAO) contributed to these efforts by the development of a Crop Simulation Model (AquaCrop). This model is characterized by its simplicity, accuracy and robustness. AquaCrop model emphasizes water as a key limiting factor in crop production, which is the difference between the actual and potential yield that can be known and determine the water use efficiency under field conditions [14] [15].

In addition the advantage of AquaCrop requires minimum data which is easy to obtain or assume. Although, these standards may not be sufficient so that data should be calibrated and adjusted to local conditions, genotypes, and crop managements practice. On the other hand, input data such as plant density, irrigation schedule, and weather data are necessary to be provided by the user of this model. The engine of plant growth in this model is driven-water from the soil that has been transpired by the plant [16] [17].

AquaCrop model converts the daily crop transpiration coefficient ( $\operatorname{Tr}$ ) directly into daily biomass production by conservative crop-specific parameters. Biomass production response to water application represents the atmosphere evaporation 
and the $\mathrm{CO}_{2}$. Therefore, the reference evapotranspiration (ETo) has been adopted in this model. As a result, this model used the plant canopy instead of leave area index to calculate transpiration and separate transpiration from soil evaporation, crop production calculated based on Biomass and harvest index.

In AquaCrop model, water deficit, which ranged between field capacity [18]. It responds to the daily water equilibrium that included all influxes, infiltration, deep percolation, evaporation, transportation, runoff, and any changes in soil water content. The effect of water deficit on crop production due to poor management of crop or water could be represented in equivalents according to relative water depletion of available water in roots' zone. These equivalents are: leaves growth, sustainability of stomata conductance plant canopy aging and failure of pollination, this activities are the most sensitive to water stress. AquaCrop should calibrate according to a geographical location under different climatic conditions, soil type, phenotype, irrigation method, and crop management to improve model simulation [19] [20].

The results of several researches [21] [22] indicated that the use of AquaCrop model to manage irrigation of the maize was satisfactory and efficient, so that these studies [23] [24] [25] recommended the use of this model to simulate maize yield response to different environmental conditions and irrigation systems. The input data from field experiment used different irrigation method that contested five irrigation methods (i.e. furrow irrigation $\left(\mathrm{I}_{0}\right)$ surface drip irrigation $\left(\mathrm{I}_{1}\right)$ and subsurface drip irrigation with three patterns of emitters depth, $10 \mathrm{~cm}\left(\mathrm{I}_{2}\right), 20 \mathrm{~cm}$ $\left(\mathrm{I}_{3}\right)$ and $30 \mathrm{~cm}\left(\mathrm{I}_{4}\right)$ were used to test of AquaCrop.

The input data standard was obtained from previous studies [26] [27] was used to add test of AcuaCrop performance validity compared to the simulation of the biomass accumulation, grain yield, harvest index, and water productivity. Data that obtained from field experiment was carried out over two consecutive seasons (2016 and 2017) under the central region of Iraq environment on maize cultivar Kalimeras hybrid F1 by using different irrigation method. The study aims at making validation and calibration of AquaCrop model by using different irrigation methods coefficients of Maize (Zea mays L.) in order to get the calibrations necessary to apply simulations and predict the use of AquaCrop model of Maize in different irrigation ways by using statistical calibration method, which will be studied for several plant measures (Water productivity, Biomass, Dry Yield and Harvest Index) and compare them with the values that are simulated by using AquaCrop model as well as study the compatibility level in accordance with statistical measurements that have used in this study.

\section{Material and Methods}

\subsection{Study Area}

Experiments were conducted in a field of a maize farmer in the Yousifya area, 15 $\mathrm{km}$ southwest of Baghdad, Iraq, which is located at $33^{\circ} 07^{\prime} 84^{\prime \prime} \mathrm{N}$ Latitude, $44^{\circ} 18^{\prime} 75^{\prime \prime} \mathrm{E}$ Longitude and $34 \mathrm{~m}$ Altitude, as shown in Figure 1. The climate of this region is 


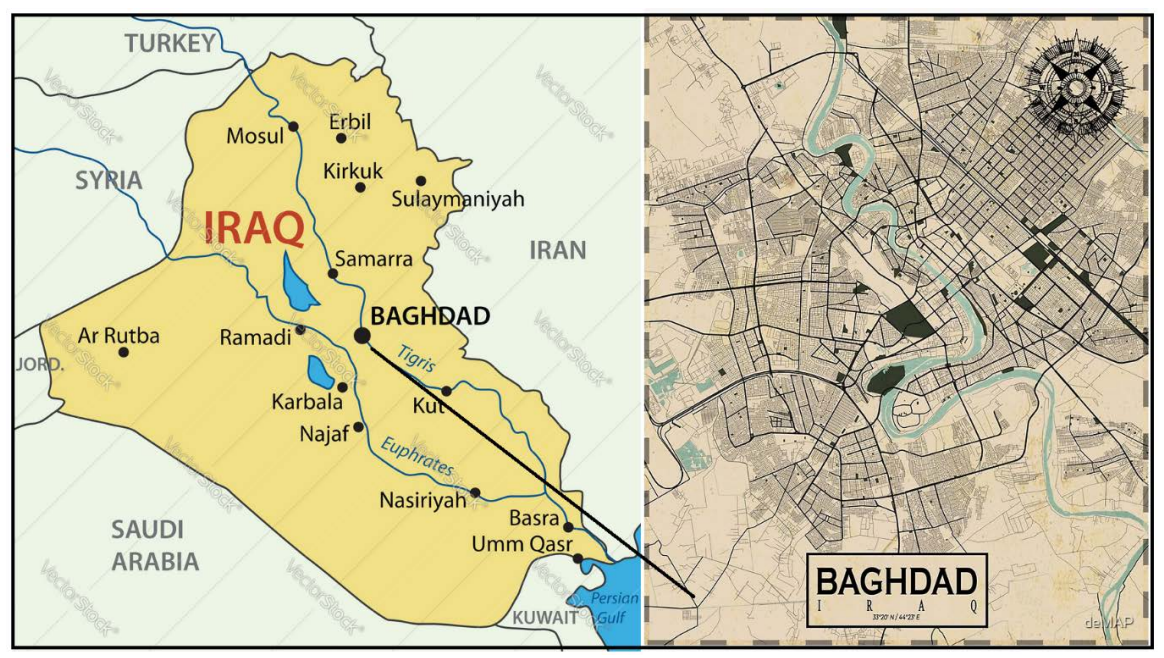

Figure 1. Experiment location in Al-Yusufiya, south of Baghdad Iraq.

characterized by high temperature, intense solar radiation, without rainfall and an increase in the evaporation rates. Figure 2 shows climate variations of maize growing during the 2016 and 2017 seasons. As for soil, some of its physical, chemical and hydraulic properties are shown in Table 1 at a depth of $0-30 \mathrm{~cm}$.

\subsection{Experimental Procedure and Treatments}

The experiment land was prepared in terms of tillage, cultivation and leveling; then, it was divided into plots to represent the experimental unities according to a randomized completely block design (RCBD) with three replicates. The measured values was analyzed using analysis of variance (ANOVA) and significant difference were tested by Least Significant Differences method (LSD) at (0.05) level. SAS version 2012 was used [28]. The experiment included five irrigation systems that were furrow irrigation $\left(\mathrm{I}_{0}\right)$ surface drip irrigation $\left(\mathrm{I}_{1}\right)$ and subsurface drip irrigation with three patterns of emitters depth, $10 \mathrm{~cm}\left(\mathrm{I}_{2}\right), 20 \mathrm{~cm}\left(\mathrm{I}_{3}\right)$ and $30 \mathrm{~cm}\left(\mathrm{I}_{4}\right)$ (Figure 3). Kalamaras maize hybrids were planted on 7 August for 2016 and 2017 seasons with a population $(62,500)$ plant ha ${ }^{-1}$. Experimental unit is fertilized with the use of $60 \mathrm{~kg} \cdot \mathrm{ha}^{-1} \mathrm{P}$ of Diamonium phosphate DAP fertilizer (18:46:0) with urea $200 \mathrm{~kg} \cdot \mathrm{ha}^{-1}$ of (N: 46\%) and $\mathrm{kg} \cdot \mathrm{ha}^{-1} 120$ Potassium sulphate $\mathrm{K}_{2} \mathrm{SO}_{4}(0: 0: 50 \%)$ [29].

\subsection{Soil Moisture and Irrigation Management}

Initial soil moisture for experimental units was measured using a gravimetric method which was converted into volumetric water content at depth $0-90 \mathrm{~cm}$ and it was divided into four layers $(0-15,15-30,30-50$ and $50-90 \mathrm{~cm})$ where the moisture for the four layers was calculated, this is used to represent soil water through the root zone. Moisture depletion was monitored in the root zone of the experimental units for the furrow irrigation treatments either as the experimental units for the drip irrigation (surface and subsurface). Moisture was monitored using a system of sensors (manufactured by Decagon Device Company) and 


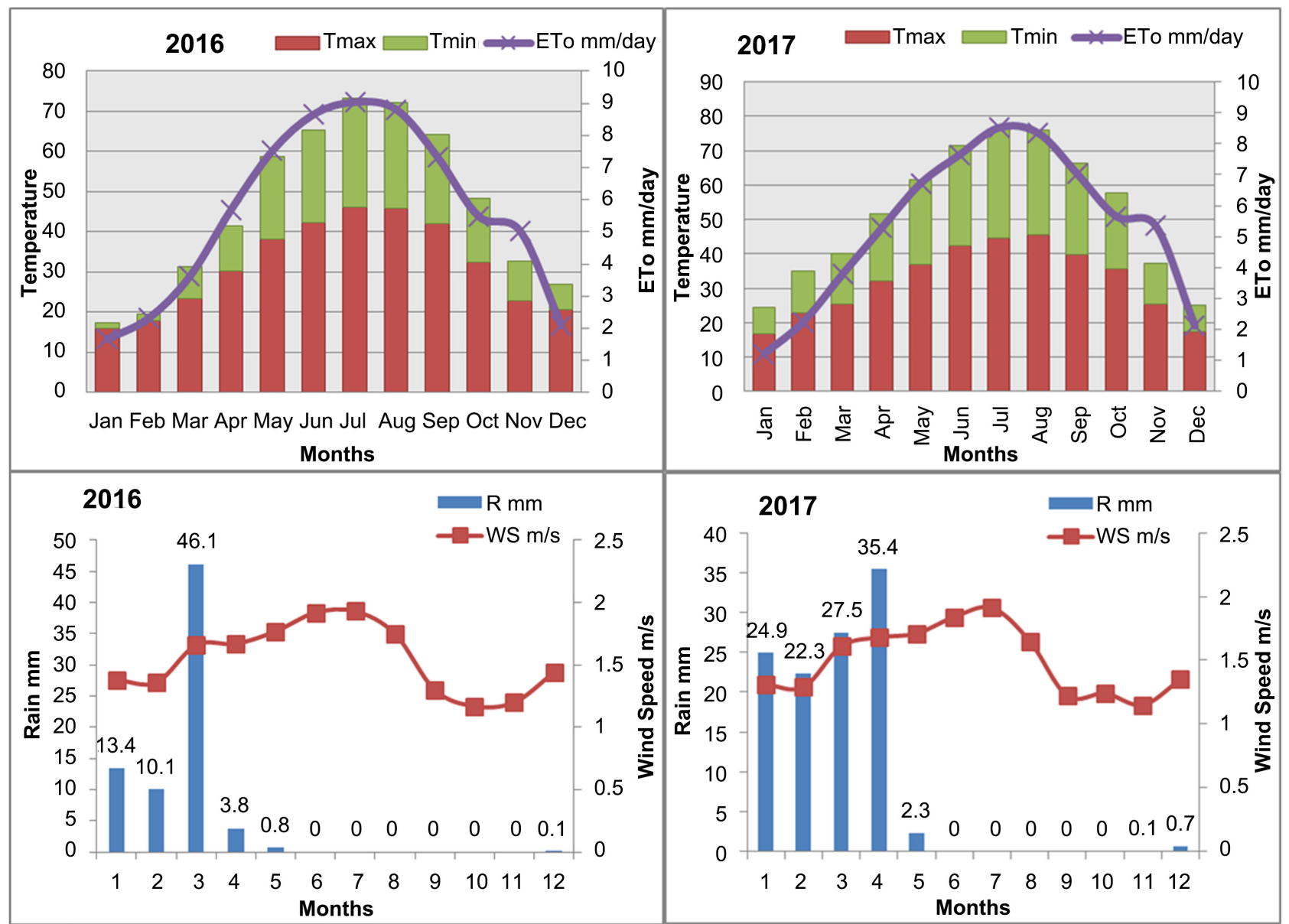

Figure 2. Temperature, total evapotranspiration and wind speed of study area in 2016 and 2017 seasons.

Table 1. Chemical and physical properties of experimental soil.

\begin{tabular}{ccc}
\hline \multirow{2}{*}{ Characteristics } & 2016 & 2017 \\
\cline { 2 - 3 } & Soil depths $(\mathbf{0}-\mathbf{3 0} \mathrm{cm})$ & Soil depths $(\mathbf{0}-\mathbf{3 0} \mathrm{cm})$ \\
\hline $\mathrm{EC}\left(\mathrm{dsm}^{-1}\right)$ & 3.2 & 3.6 \\
$\mathrm{pH}$ & 7.6 & 7.8 \\
Sand (\%) & 122 & 115 \\
Silt $(\%)$ & 624 & 648 \\
Clay $(\%)$ & 254 & 237 \\
Dominant texture & Silty Clay & Silty Clay \\
Organic Matter $(\%)$ & 4.50 & 3.73 \\
Bulk Density $\left(\mathrm{mg} \cdot \mathrm{m}^{-3}\right)$ & 1.38 & 1.39 \\
Particle Density $\left(\mathrm{mg}^{-3} \mathrm{~m}^{-3}\right)$ & 2.58 & 2.60 \\
Porosity $(\%)$ & 48 & 49 \\
Water Content at $33 \mathrm{kPa}\left(\mathrm{cm}^{3} \cdot \mathrm{cm}^{-3}\right)$ & 0.3361 & 0.3368 \\
Water Content at $1500 \mathrm{kPa}\left(\mathrm{cm}^{3} \cdot \mathrm{cm}^{-3}\right)$ & 0.1777 & 0.1779 \\
Available Water $\left(\mathrm{cm} \cdot \mathrm{cm}^{-3}\right)$ & 0.1584 & 0.1589 \\
\hline
\end{tabular}




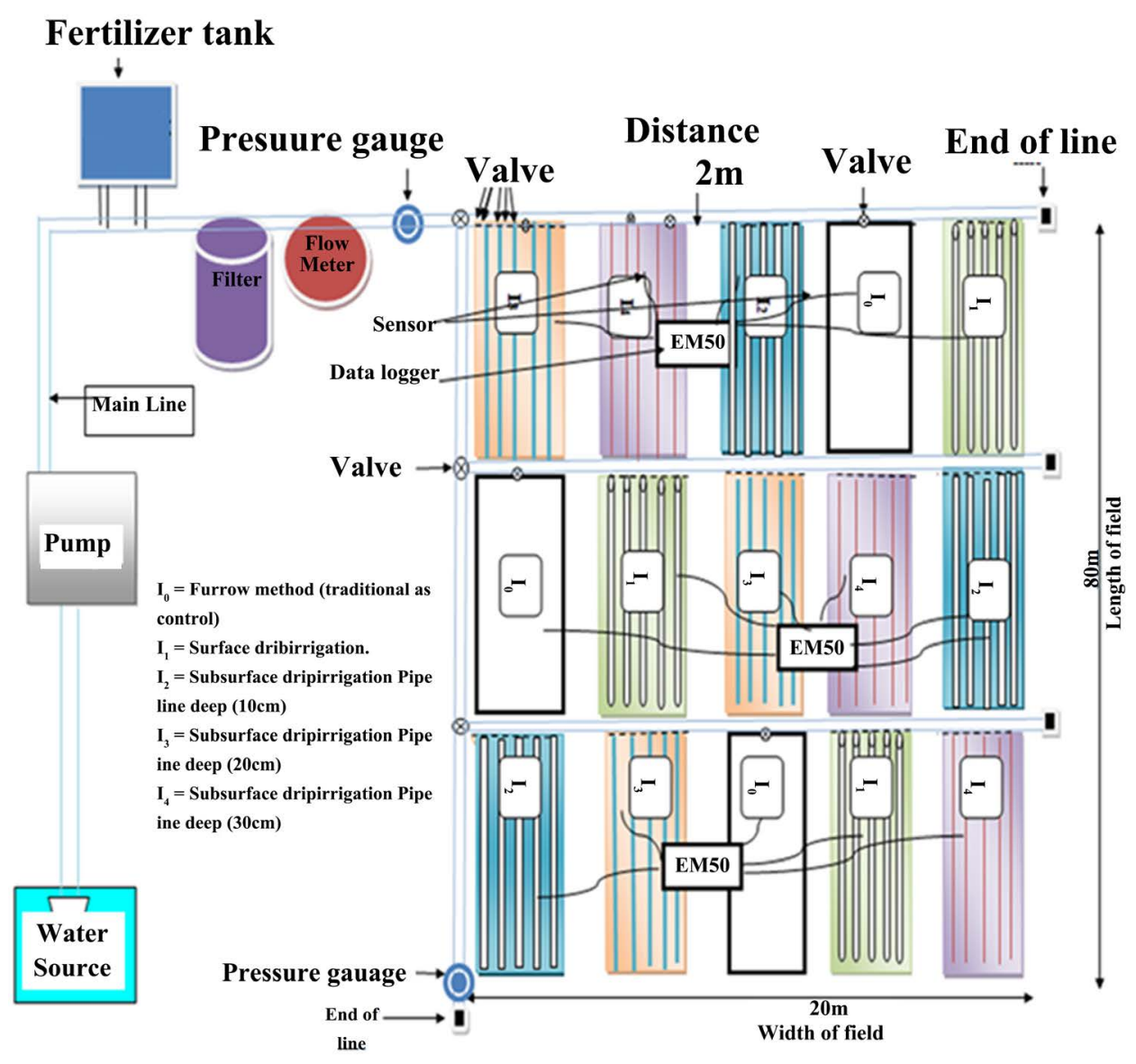

Figure 3. Layout of experimental treatments.

connected to the drip irrigation system that was used for the irrigation experimental unities $I_{1}, I_{2}, I_{3}$ and $I_{4}$ treatments irrigation frequency applied. After 50\% of available water is depleted at the root zone (available water is equal to the percentage of soil moisture between the field capacity and wilting point).

The irrigation for $I_{0}$ treatment was applied by tubers with valves and flow meter to measure the amount of added water to experimental units of this treatment as in the following equation [30]:

$$
d=\left(\theta_{F C}-\theta_{w}\right) D
$$

where:

$d=$ Depth of water applied $(\mathrm{mm})$,

$\theta_{F C}=$ Volumetric water content at field capacity,

$\theta_{W}=$ Volumetric water content before irrigation (depletion $50 \%$ of available water), and

$D=$ Effective root depth ( $\mathrm{mm})$.

As for the amount of water added to the experimental units for drip irrigation treatments $\left(I_{1}, I_{2}, I_{3}\right.$ and $\left.I_{4}\right)$, it was calculated according to the following equation [31]:

$$
N D I=R Z D \times W H C \times P d \times P w
$$


where:

$N D I=$ Net depth irrigation $(\mathrm{cm})$,

$R Z D=$ Root zone depth $(\mathrm{cm})$,

$W H C=$ Water bearing capacity $\left(\mathrm{mm}\right.$ of water in $\left.\mathrm{cm}^{-1}\right)$,

$P d=$ Percent of depletion (\%), and $P W=$ Percent of wetting (\%).

The net irrigation requirement was calculated using soil water balance as in the following equation [32]:

$$
(I+P+C)-\left(E T_{a}+D+R\right)=\mp \Delta s
$$

where:

$P=$ precipitation $(\mathrm{mm}), C=$ capillaries $(\mathrm{mm})$,

$I=$ irrigation $(\mathrm{mm})$,

$D=$ deep percolation $(\mathrm{mm})$,

$E T_{a}=$ actual evapotranspiration $(\mathrm{mm})$,

$R=\operatorname{runoff}(\mathrm{mm})$,

$\Delta s=$ changes in the water storage during soil profile,

$C=0$ (limited contribution, water table depth $=3 \mathrm{~m}$ ),

$R=0$ (no surface runoff),

$P=0$ (no rain),

$D=0$ (So irrigation at field efficiency is limited to the degradation).

Equation (3) becomes:

$$
I+P-E T_{a}= \pm \Delta s
$$

Throughout the present study, at the beginning of the study, the soil water content was observed to be similar to its content at the end of the experiment, $\Delta s=$ 0 . The equation for water-consuming use becomes:

$$
I=E T_{a}
$$

Water use efficiencies were determined equation [33]:

$$
W U E_{f}=\frac{G Y}{W A}
$$

where:

$$
\begin{aligned}
& W U E_{f}=\text { field water use efficiency }\left(\mathrm{kg} \cdot \mathrm{m}^{3}\right), \\
& G Y=\text { total grain yield }\left(\mathrm{kg} \cdot \mathrm{ha}^{-1}\right), \\
& W A=\text { water applied }\left(\mathrm{m}^{3} \cdot \mathrm{ha}^{-1}\right) .
\end{aligned}
$$

\subsection{Crop Measurements}

Maturity biomass and grain yield were measured on dry weight after harvesting, harvest index was calculated as the ratio of grain yield to the total above-ground dry mass of shoot. As for water productivity, it was calculated by dividing the grain yield by the amount of water given to the crop.

\subsection{Model Validation and Calibration}

AquaCrop model was calibrated for simulating predicting maize growth and prod- 
uctivity under the field conditions of our study. Conservative and generally applicator parameters of the crop data file of AquaCrop with values were used is shown in Table 2. Then, we tested the calibrated model with two years of measured data (2016 and 2017).

The simulation was mainly focused on aboveground biomass, grain yield, harvest index and water productivity. There is a great need to calibrate the AquaCrop model, which includes the need to adjust to the original standards that apply before the model is used for simulation prediction. Calibration is done by including datasets on: climate, soil, crop and field management practices and also we need to modify some inputs such as planting date, plant population's plant growth stages duration [18] [34].

\subsection{Statistical Comparison}

Five Statistical measurements were applied to test the performance of the model and compare the simulated and measured results:

Table 2. Calibrated maize parameters of AquaCrop model used in this study.

\begin{tabular}{|c|c|}
\hline Parameters & Calibrated values \\
\hline Base temperature ${ }^{\circ} \mathrm{C}$ & 9 \\
\hline Cut-off temperature ${ }^{\circ} \mathrm{C}$ & 45 \\
\hline Canopy cover per seedling $\left(\mathrm{cm}^{2}\right.$ plant $\left.^{-1}\right)$ & 6.7 \\
\hline "Maximum rooting depth $(\mathrm{m}) "$ & 1.5 \\
\hline Crop coefficient for transpiration (Kcb) & 1.08 \\
\hline "Canopy expansion stress coefficient (Pupper)" & 0.13 \\
\hline Canopy expansion stress coefficient (Plower) & 0.68 \\
\hline "Canopy expansion curve shape" & 2.5 \\
\hline Stomatal conductance threshold (Pupper) & 0.33 \\
\hline "Stomatal closure shape factor." & 5 \\
\hline Canopy senescence stress coefficient (Pupper) & 0.41 \\
\hline "Canopy senescence shape factor." & 2.5 \\
\hline Aeration stress coefficient (\% vol saturation) & 4 \\
\hline "Canopy decline coefficient $\left(\% \mathrm{GDD}^{-1}\right)$ " & 0.69 \\
\hline Reference harvest index (\%) & 46 \\
\hline "Crop growth stages (GDD)" & - \\
\hline Time from sowing to emergence & 152 \\
\hline "Time from sowing to max canopy cover." & 1440 \\
\hline Time from sowing to senescence & 2400 \\
\hline "Time from sowing to maturity." & 2880 \\
\hline Time from sowing to flowering & 1368 \\
\hline "Length of flowering stage." & 240 \\
\hline
\end{tabular}


1) Root Mean Square Error (RMSE):

$$
R M S E=\sqrt{\frac{1}{n} \sum_{i=1}^{n}(S i-M i)^{2}}
$$

where: $S i$ and $M i$ are simulated and measured values; respectively, and $n$ is the number of observations.

2) Coefficient of Determination $\left(R^{2}\right)$ :

$$
R^{2}=\frac{\sum S i M i-\sum S i+\sum M i}{\sqrt{\sum S i^{2}-\left(\sum S i\right)^{2}} \times \sqrt{\sum M i^{2}-\left(\sum M i\right)^{2}}}
$$

3) Mean Bias Error $(M B E)$ :

$$
M B E=\frac{1}{n} \sum_{i=1}^{n}(S i M i)
$$

4) Index of agreement (d) of [35]:

$$
d=1-\frac{\sum_{i=1}^{n}(S i-M i)^{2}}{\sum_{i=1}^{n}(S i-\bar{M}|+M i-\bar{M}|)^{2}}
$$

where: $\bar{M}$ is the mean of the $n$ measured values, and value of $d$ range from- $\infty$ to 1.0 .

5) Coefficient of Efficiency $(E)$

$$
E=1-\frac{\sum_{i=1}^{n}(S i-M i)^{2}}{\sum_{i=1}^{n}(M i-\bar{M})^{2}}
$$

\section{Results and Discussion}

Simulation values of AquaCrop model were compared with data obtained from the field experiment which was carried out for two seasons (2016 and 2017). This included five treatments for irrigation of maize under the natural conditions of the central region of Iraq, and the cultivation of hybrid Kalimeras (F1). Table 3 show the results of the simulated and measured values of the parameters for Aqua Crop, that was used for calibration the model, shows that the range of the calibrated values is well matching within the recommended vicinity of the simulated and the measured values and illustrated that the average calibrated values of the parameters are close to the simulated value for all irrigation treatments in this study for 2016 and 2017 seasons.

The values of the statistical analysis confirmed the accuracy of the calibration of AquaCrop in its simulation of the biomass, grain yield, harvest index and water productivity in the (Table 3 ). The model shows high correlation (1:1) between simulated and measured values. Generally, the correlation values $\left(R^{2}\right)$ were (0.98 and 0.99) for Biomass, (0.99 and 0.99) for grain yield, and (0.99 and 0.97) for harvest index for the two seasons of 2016 and 2017; respectively. While the $\left(R^{2}\right)$ for water productivity was $(0.8$ and 0.75$)$ for the 2016 and 2017 ; respectively this indicates that the model has predicted a high degree of accuracy with respect to Biomass, grain yield and harvest index and this was confirmed by the 
Table 3. Statistical indexes of AquaCrop simulated and measured results for the calibration datasets.

\begin{tabular}{cccccc}
\hline Observation & $R^{2}$ & $R M S E$ & $M B E$ & $E$ & $d$ \\
\hline Biomass $\left(\mathrm{t} \cdot \mathrm{ha}^{-1}\right)$ & 0.98 & 0.33 & -0.32 & 0.87 & 0.971 \\
Grain Yield $\left(\mathrm{t} \cdot \mathrm{ha}^{-1}\right)$ & 0.99 & 0.30 & -0.29 & 0.82 & 0.958 \\
Harvest Index & 0.99 & 0.84 & -0.77 & 0.92 & 0.978 \\
Water productivity $\left(\mathrm{kg} \cdot \mathrm{m}^{3}\right)$ & 0.80 & 0.49 & -0.19 & 0.37 & 0.641 \\
& & 2017 & & & \\
Biomass $\left(\mathrm{t} \cdot \mathrm{ha} \mathbf{a}^{-1}\right)$ & 0.99 & 0.28 & -0.24 & 0.90 & 0.972 \\
Grain Yield $\left(\mathrm{t} \cdot \mathrm{ha} \mathrm{a}^{-1}\right)$ & 0.99 & 0.26 & -0.25 & 0.87 & 0.970 \\
Harvest Index & 0.97 & 0.83 & -0.74 & 0.85 & 0.960 \\
Water productivity $\left(\mathrm{kg} \cdot \mathrm{m}^{3}\right)$ & 0.73 & 0.59 & -0.30 & 0.26 & 0.600 \\
\hline
\end{tabular}

low (RMSE), ( $d$ ) and (E) values (Table 3). While the $d$ and $E$ values were moderate for water productivity as they reached $(0.37$ and 0.26$)$ in relation to $E$ (0.641 and 0.600) in relation to (d) for the two seasons 2016 and 2017, respectively.

The $(M B E)$ values suggested that AquaCrop reduce biomass, grain yield, harvest index and water productivity during calibration and none of these attributes have been overestimated during calibration. It was found that the highest decrease in harvest index ( -0.77 and -0.74$)$ for the two seasons 2016 and 2017; respectively while the lowest decrease was in water productivity it was $(-0.19)$ in 2016 and $(-0.30)$ in 2017 similar result are obtained by precise the authors [36] [37]. The (MBE) values of biomass $(-0.32$ and -0.24$)$ and for the grain yield $(-0.29$ and -0.25 ) for the two seasons 2016 and 2017; respectively. The approximation of values for the two seasons indicates that the model was well able to simulate the values and their compatibility with the measured similar result are obtained by [38].

Through this study and Based on the performance evaluation of the AquaCrop model, which showed the simulation of biomass, grain yield and harvest index are reliable so that he simulated values of the Aquacrop model did not exceed $2.4 \%, 5.8 \%, 3.4 \%$ for each biomass, grain yield, harvest index respectively. These results are similar to the results of the others who test the validity of the Aquacrop model for irrigation management of maize [18] [19].

Table 4 and Figures 4-8 show the percentage of deviation between the simulated and measured values, which ranged between $1.3 \%$ in $\mathrm{I}_{2}$ and $2.4 \%$ in $\mathrm{I}_{3}$ and $0.9 \%$ in $\mathrm{I}_{1}$ and $2.0 \%$ in $\mathrm{I}_{3}$ treatments for biomass in 2016 and 2017seasons, respectively. As for the grain yield, it ranged between $2.5 \%$ in $\mathrm{I}_{2}$ to $5.5 \%$ in $\mathrm{I}_{1}$ and $2.1 \%$ in $\mathrm{I}_{0}$ and $4.0 \%$ in $\mathrm{I}_{3}$ treatments for 2016 and 2017 seasons, respectively. This indicates that there is a correspondence between measured and simulated values of the AquaCrop model for biomass and grain yield under different irrigation 
Table 4. Simulation values were compared with the measured value and standard deviations of biomass $\left(\mathrm{t} \cdot \mathrm{ha}^{-1}\right)$ and grain yield $\left(\mathrm{t} \cdot \mathrm{ha}^{-1}\right)$ for maize under different irrigation methods for the 2016 and 2017 seasons.

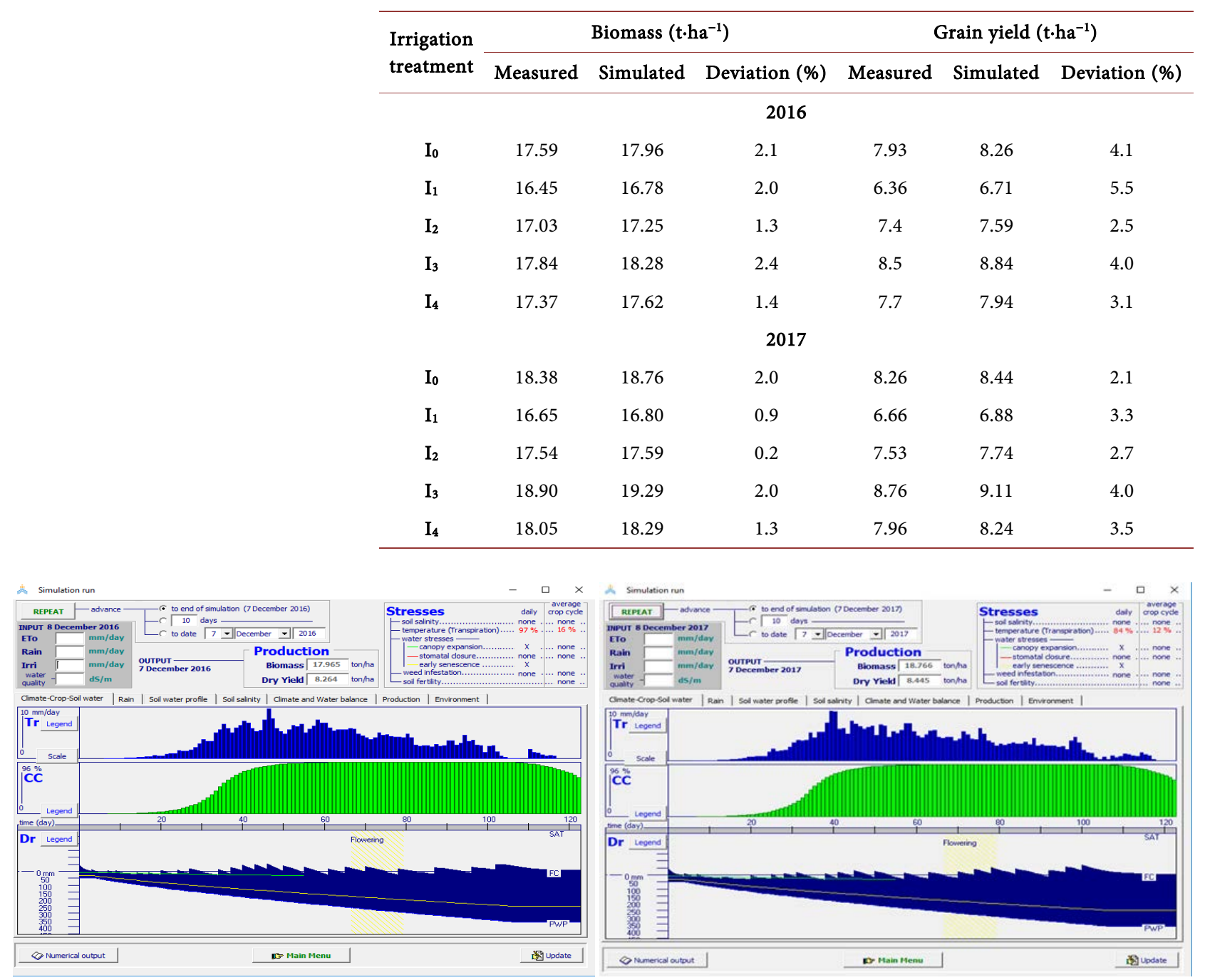

Figure 4. Biomass and grain yield for $\mathrm{I}_{0} 2016$ and 2017 seasons.
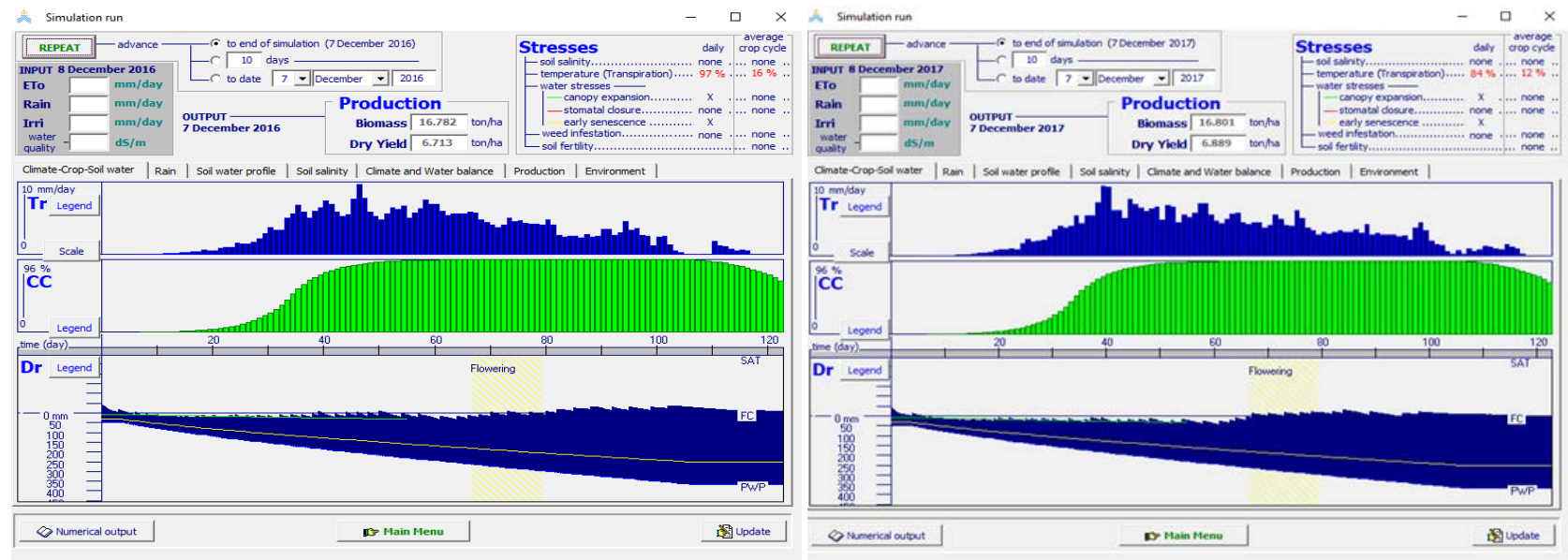

Figure 5. Biomass and grain yield for $\mathrm{I}_{1} 2016$ and 2017 seasons. 

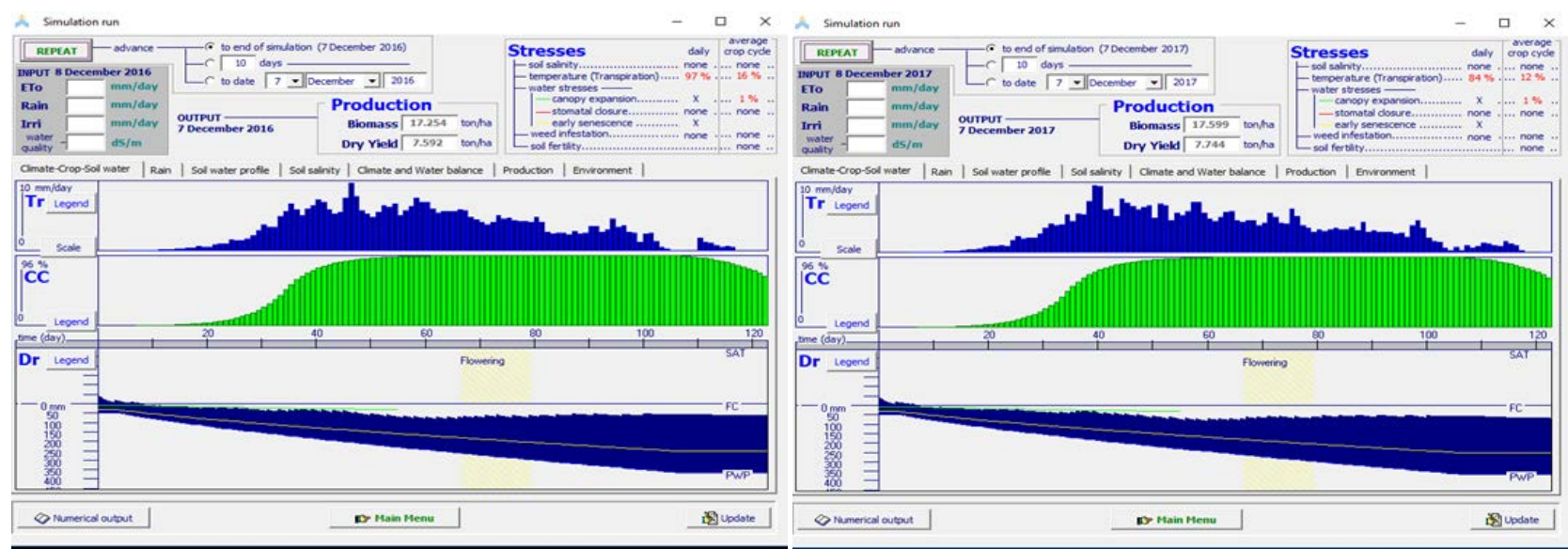

Figure 6. Biomass and grain yield for $I_{2} 2016$ and 2017 seasons.
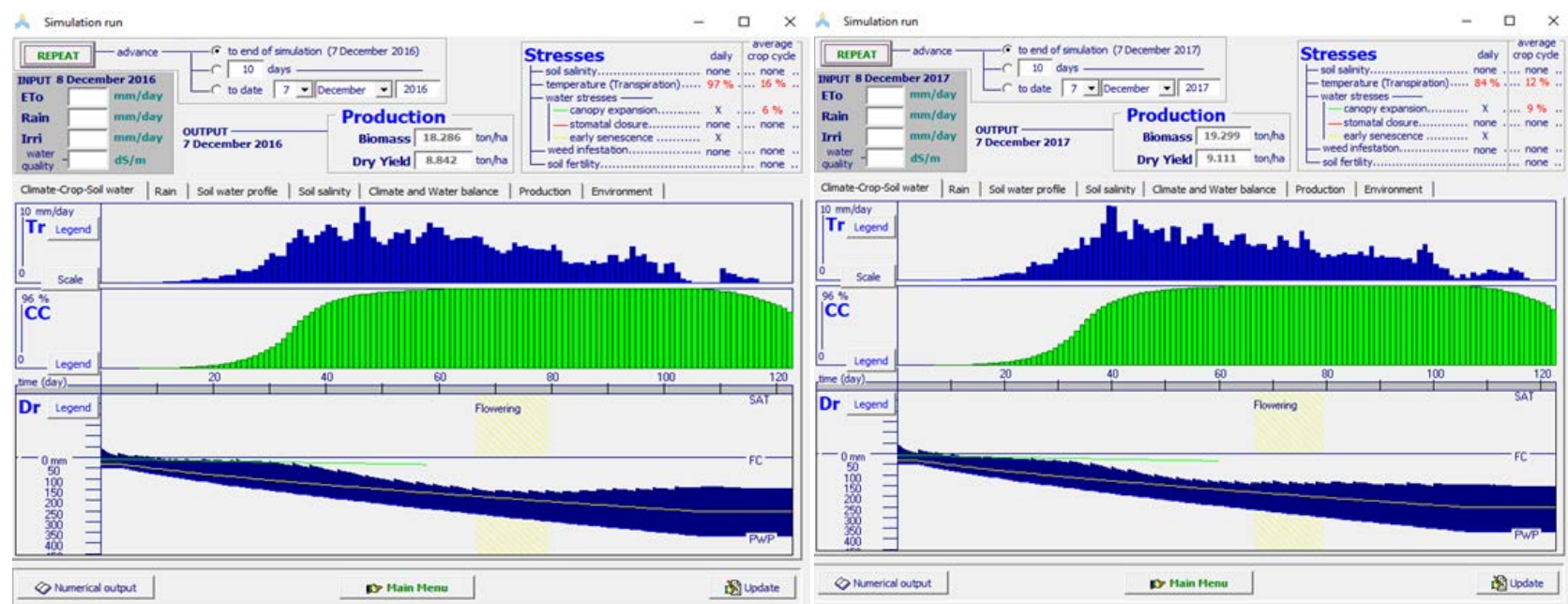

Figure 7. Biomass and grain yield for $\mathrm{I}_{3} 2016$ and 2017 seasons.
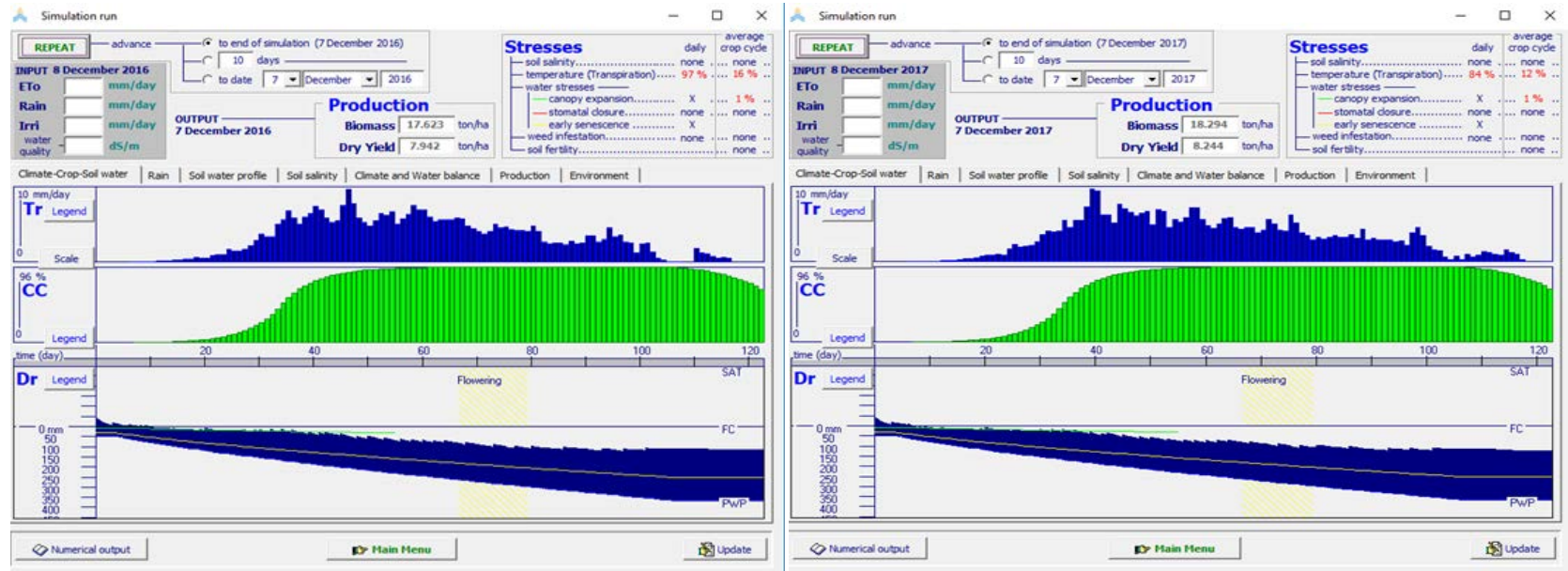

Figure 8. Biomass and grain yield for $\mathrm{I}_{4} 2016$ and 2017 seasons.

methods confirming the models validity for use in irrigation management of the maize. These results are consistent with findings of precise the authors [39] [40]. 
Simulating the final harvest index for all treatments are shown in Table 5 and Figures 9-13. Deviation ranged for the harvest index values between $3.4 \%$ for $\mathrm{I}_{1}$ treatment in 2016 as the highest value and lowest values of $0.1 \%$ for $\mathrm{I}_{0}$ in 2017 season. The deviation from the harvest index values is very low due to the matching between the values of biomass and grain yield. Biomass and grain yield were slightly underestimating for all treatments. However, it was well matching within the recommended vicinity of the default and the measured values. As for water productivity, it showed high-value deviations between dated and measured that ranged between $+38.3 \%$ for $\mathrm{I}_{0}$ treatment in 2016 season and $-32.7 \%$ in 2017 season. Deviation values for water productivity were negative for some irrigation treatments $\mathrm{I} 2(-9 \%), \mathrm{I}_{3}(-30.22)$ and $\mathrm{I}_{4}(-24.2)$ in 2016 season and $\mathrm{I}_{2}(-14.6 \%)$,

Table 5. Simulation values were compared with the measured value and standard deviations of harvest index and water productivity $\left(\mathrm{kg} \cdot \mathrm{m}^{-3}\right)$ for maize under different irrigation methods for the 2016 and 2017 seasons.

\begin{tabular}{ccccccc}
\hline \multirow{2}{*}{$\begin{array}{c}\text { Irrigation } \\
\text { treatment }\end{array}$} & \multicolumn{3}{c}{ Harvest Index } & \multicolumn{3}{c}{ Water productivity $\left(\mathrm{kg} \cdot \mathrm{m}^{-3}\right)$} \\
\cline { 2 - 6 } & Measured & Simulated & Deviation (\%) & Measured & Simulated & Deviation (\%) \\
\hline $\mathrm{I}_{0}$ & 45.1 & 46.00 & 2.0 & 1.12 & 1.55 & 38.3 \\
$\mathrm{I}_{1}$ & 38.66 & 40.00 & 3.4 & 1.14 & 1.3 & 14.0 \\
$\mathrm{I}_{2}$ & 43.42 & 44.00 & 1.3 & 1.85 & 1.68 & -9.0 \\
$\mathrm{I}_{3}$ & 47.65 & 48.00 & 0.7 & 2.71 & 1.89 & -30.2 \\
$\mathrm{I}_{4}$ & 44.33 & 45.00 & 1.5 & 2.23 & 1.69 & -24.2 \\
& & & 2017 & & & \\
$\mathrm{I}_{0}$ & 44.95 & 45.00 & 0.1 & 1.2 & 1.62 & 35.0 \\
$\mathrm{I}_{1}$ & 39.97 & 41.00 & 2.5 & 1.26 & 1.32 & 4.7 \\
$\mathrm{I}_{2}$ & 42.97 & 44.00 & 2.4 & 1.98 & 1.69 & -14.6 \\
$\mathrm{I}_{3}$ & 46.38 & 47.00 & 1.3 & 2.99 & 2.01 & 32.7 \\
$\mathrm{I}_{4}$ & 44.02 & 45.00 & 2.2 & 2.45 & 1.72 & -29.7 \\
\hline
\end{tabular}
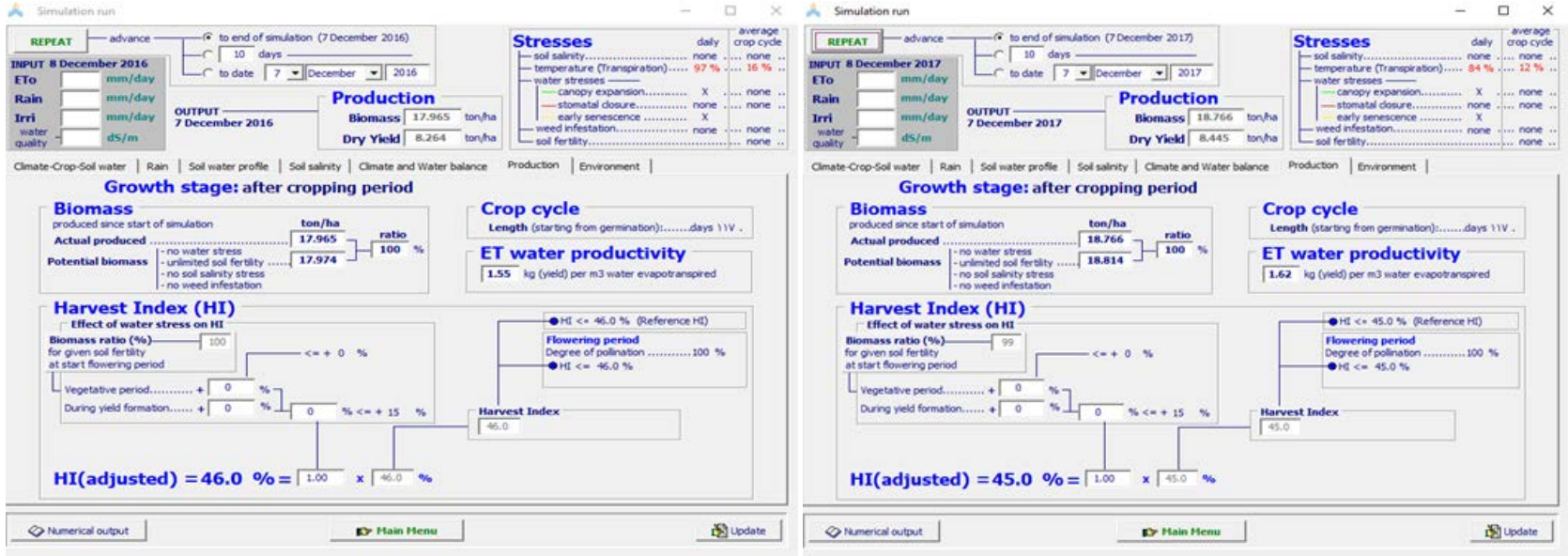

Figure 9. Harvest index and water productivity for I0 2016 and 2017 seasons. 


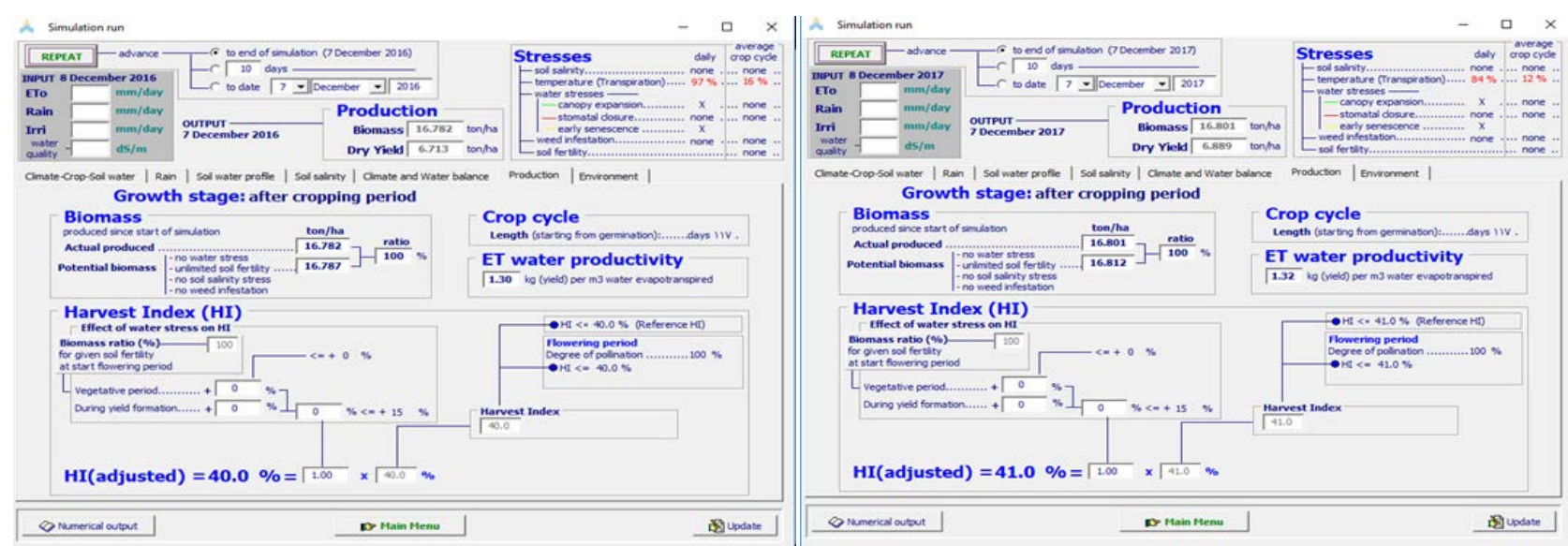

Figure 10. Harvest index and water productivity for $\mathrm{I}_{1} 2016$ and 2017 seasons.
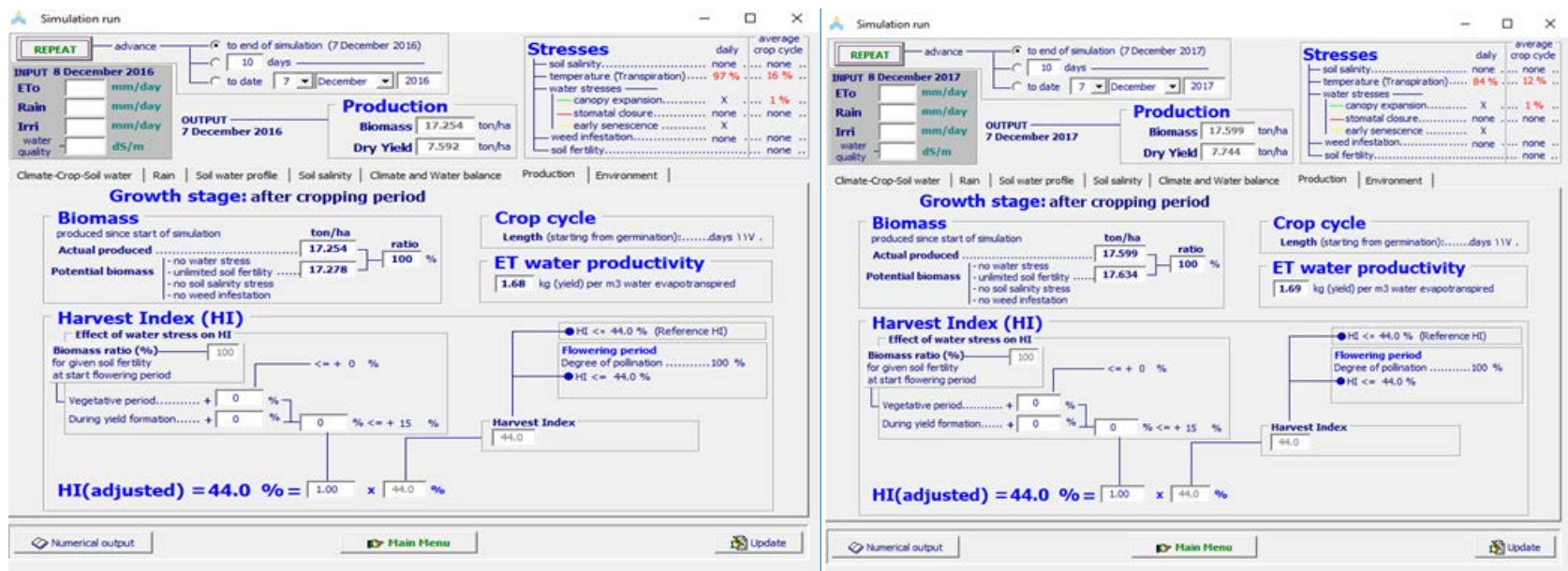

Figure 11. Harvest index and water productivity for $I_{2} 2016$ and 2017 seasons.
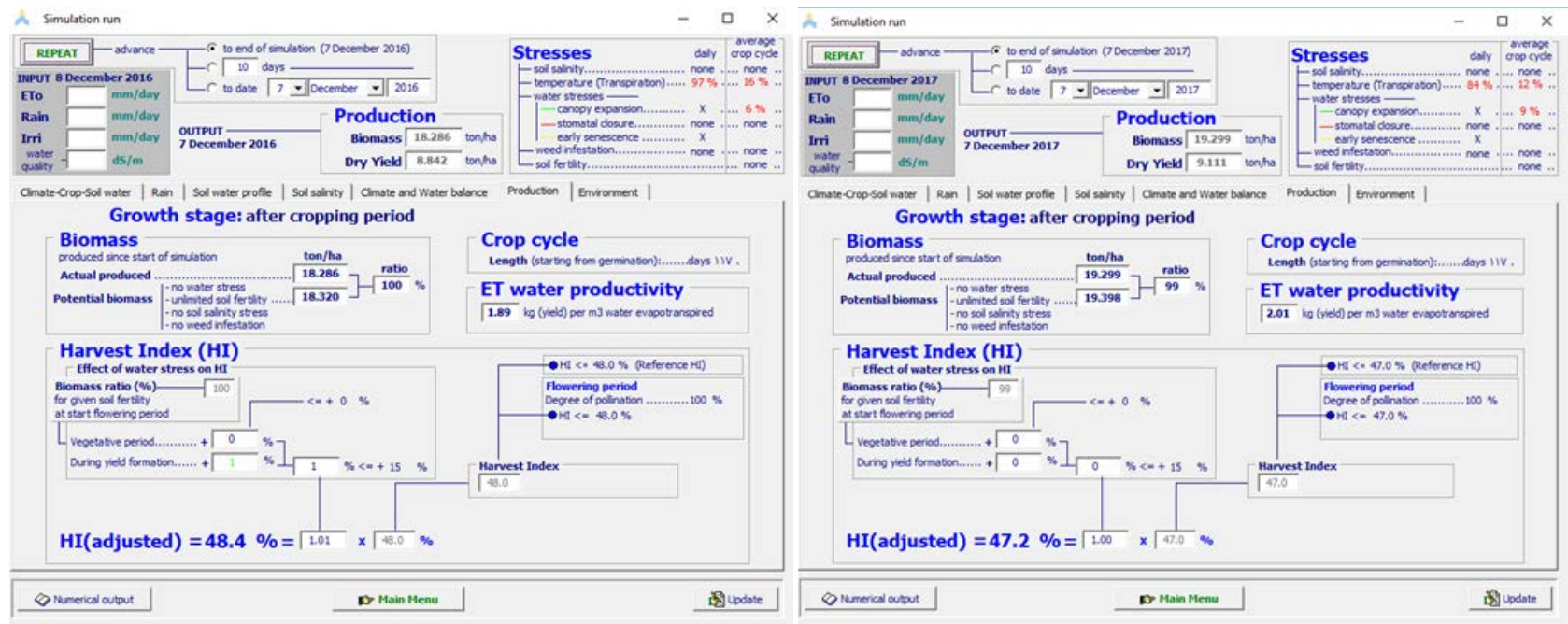

Figure 12. Harvest index and water productivity for $\mathrm{I}_{3} 2016$ and 2017 seasons.

$\mathrm{I}_{3}(-32.7 \%)$ and $\mathrm{I}_{4}(-29.75 \%)$ in 2017 season, and positive for others $\mathrm{I}_{0}(30.3 \%)$ and $I_{1}(14 \%)$ in 2016 season and $I_{0}(35 \%)$ and $I_{1}(4.7 \%)$ in 2017 season. The 


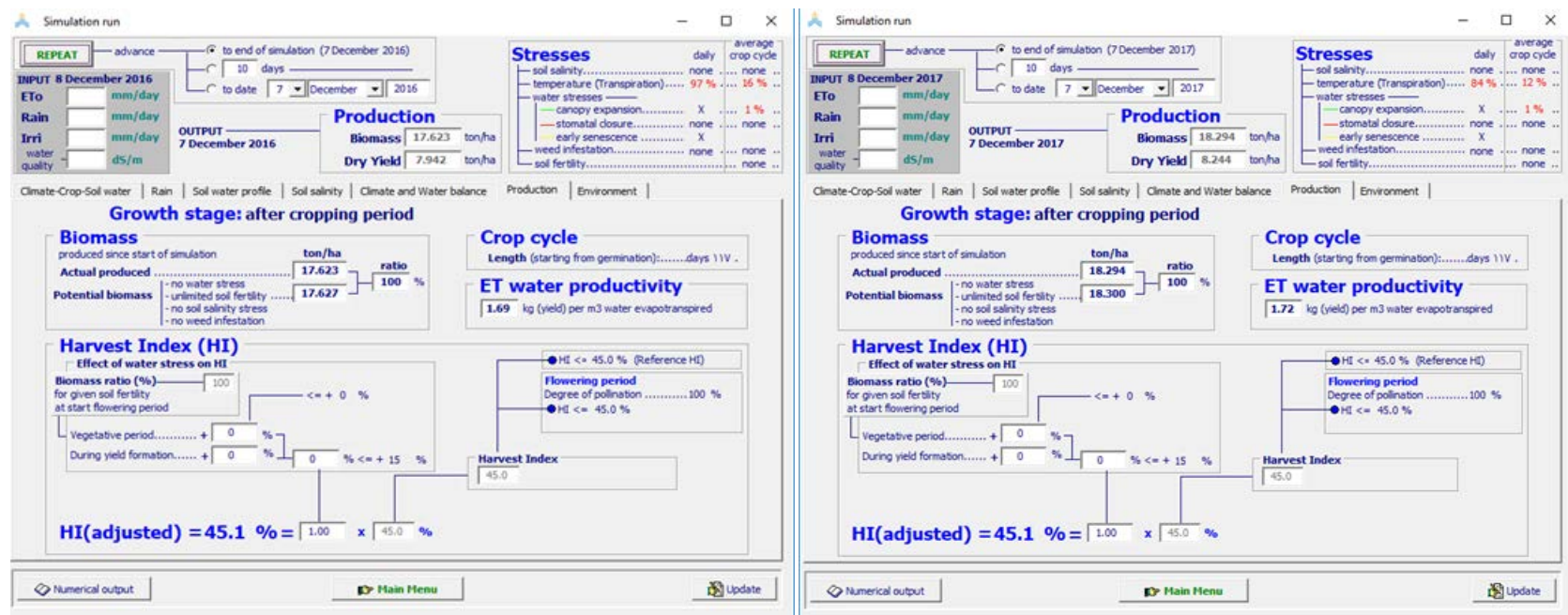

Figure 13. Harvest index and water productivity for $\mathrm{I}_{4} 2016$ and 2017 seasons.

increase in the deviation values between the simulated and measured values of water productivity may be due to the increased water requirement for $\mathrm{I}_{0}$ treatment, and as a result of losses due runoff, deep percolation and evaporation compared to subsurface drip and the low water productivity in surface drip irrigation $I_{1}$ treatment This because the water droplets that fall on the surface of the soil are exposure to evaporation because the soil texture is heavy and does not allow the water to percolate in the depths of the soil quickly and due to the high temperature and exposure of the soil surface to direct sun radiation. Meaning that the evaporation of water is faster than its percolation to root zone, As for the furrow irrigation $I_{0}$ treatment, the soil receives a sufficient amount of moisture because the water column cause a pressure that helps to quickly Percolation the wash to the depths of the soil where the root zone.

However, the disadvantage of this method are losses due to surface run off deep percolation and evaporation from the soil surface Therefore water requirements in crease which reduces the water use efficiency for this method and since the efficiency of water use is the a main goal for the irrigation process in arid and semi-and regions. Water productivity is a measure of water use efficiency, and the efficiency is determined by their two factors the amount of irrigation water used and the amount of grain yield produced according to the Equation (6), as the efficiency to water use decrease as the amount of water used increase and this is what happened with the furrow irrigation method, or the yield may decrease by a high percentage, despite the decrease in the amount of water used, which cause a decrease in the efficiency of water use, which reflects on water productivity. [41] [42]. Thus, AquaCrop model is efficient in managing the irrigation of maize and predicting the outputs that will be obtained.

Figures 14-16 show that the simulated values of biomass, grain yield and harvest index had been concentrated to be close to the line 1:1 and this explains the overestimation or underestimation in yield between simulated and experimental values The low mean value of biomass, grain yield and harvest index in 


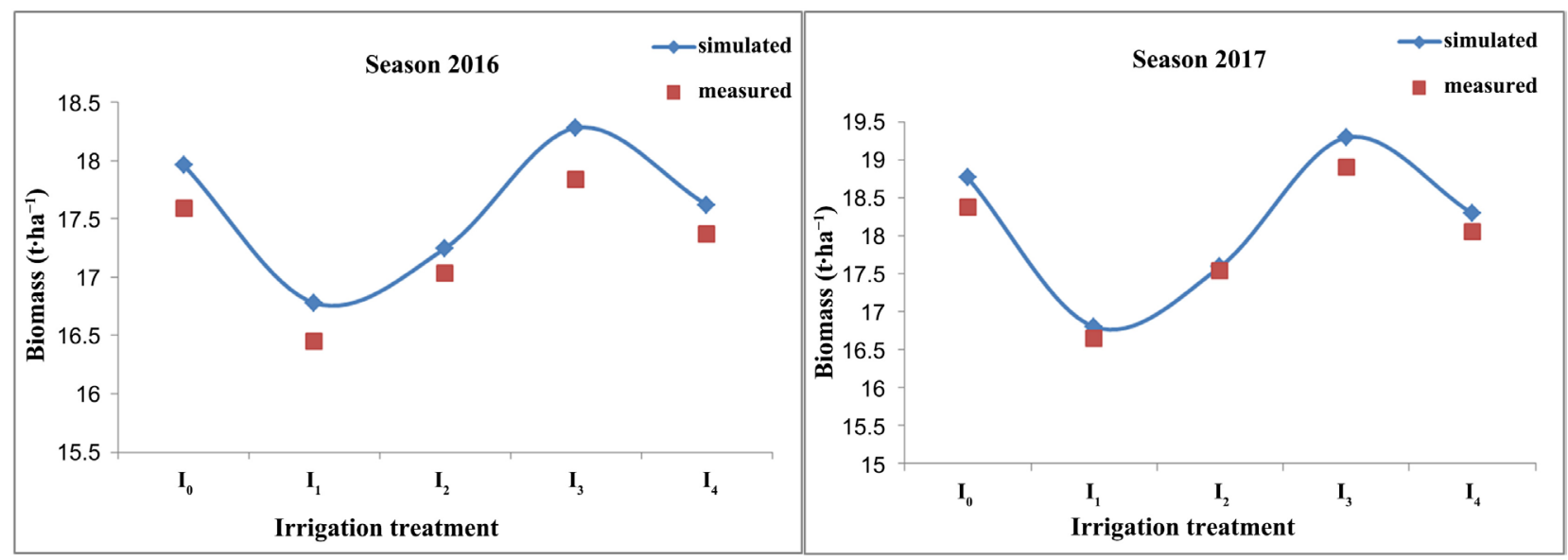

Figure 14. Simulated and measured biomass $\left(\mathrm{t} \cdot \mathrm{ha}^{-1}\right) 2016$ and 2017 seasons.
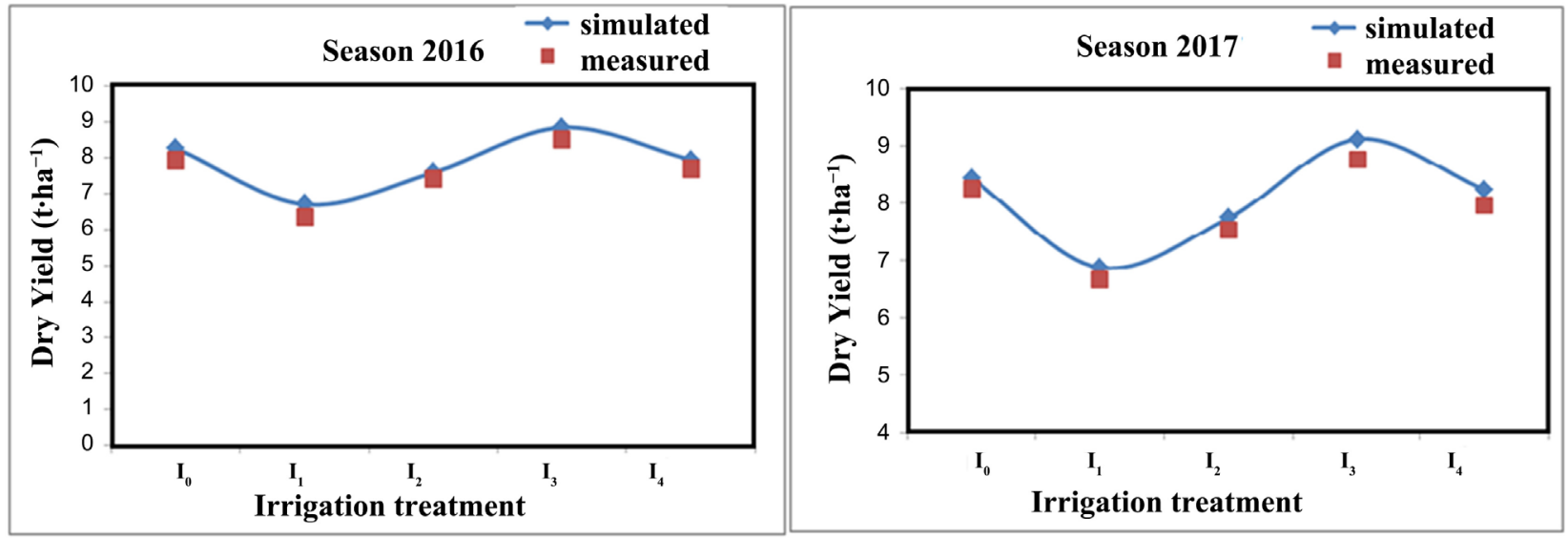

Figure 15. Simulated and measured dry yield $\left(\mathrm{t} \cdot \mathrm{h} \mathrm{a}^{-1}\right) 2016$ and 2017 seasons.
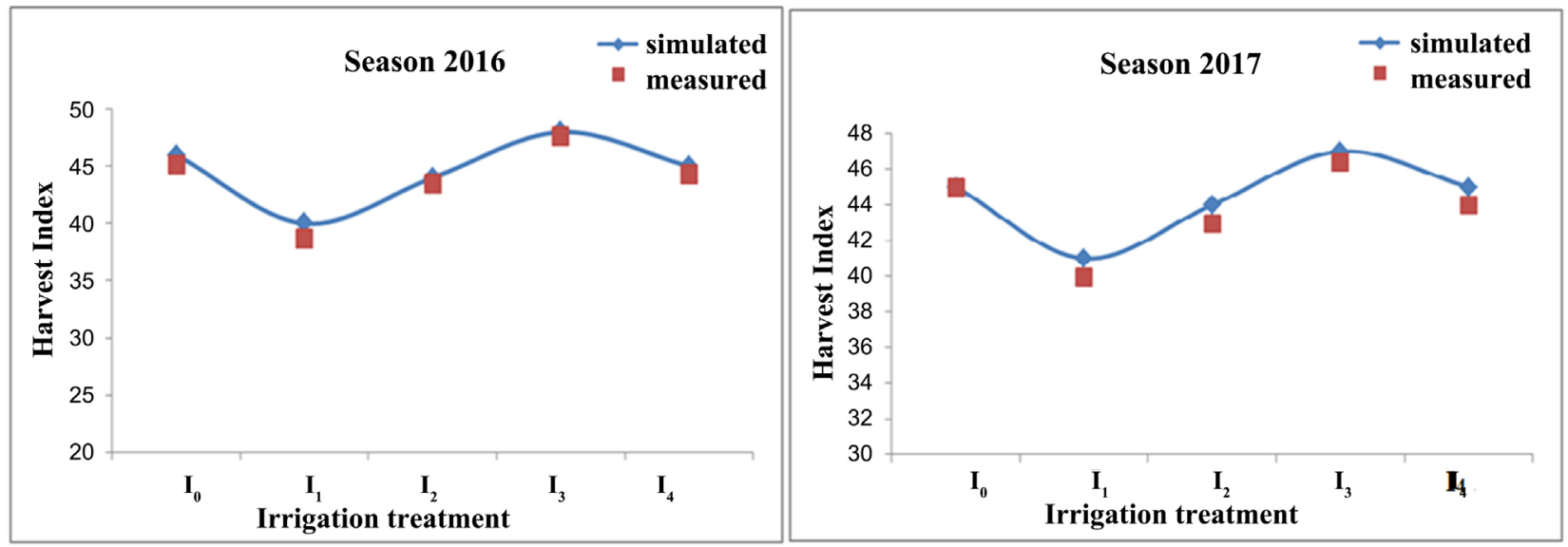

Figure 16. Simulated and measured harvest index 2016 and 2017 seasons.

the surface and subsurface drip irrigation $I_{1}$ and $I_{2}$ treatments are due to decrease of moisture, lead to disturbance such as photosynthesis, respirator, erosion, water absorption and nutrients. It also affects the cellular division that leads to a decrease in the number of divided cells and prolong the period needed to divide, 

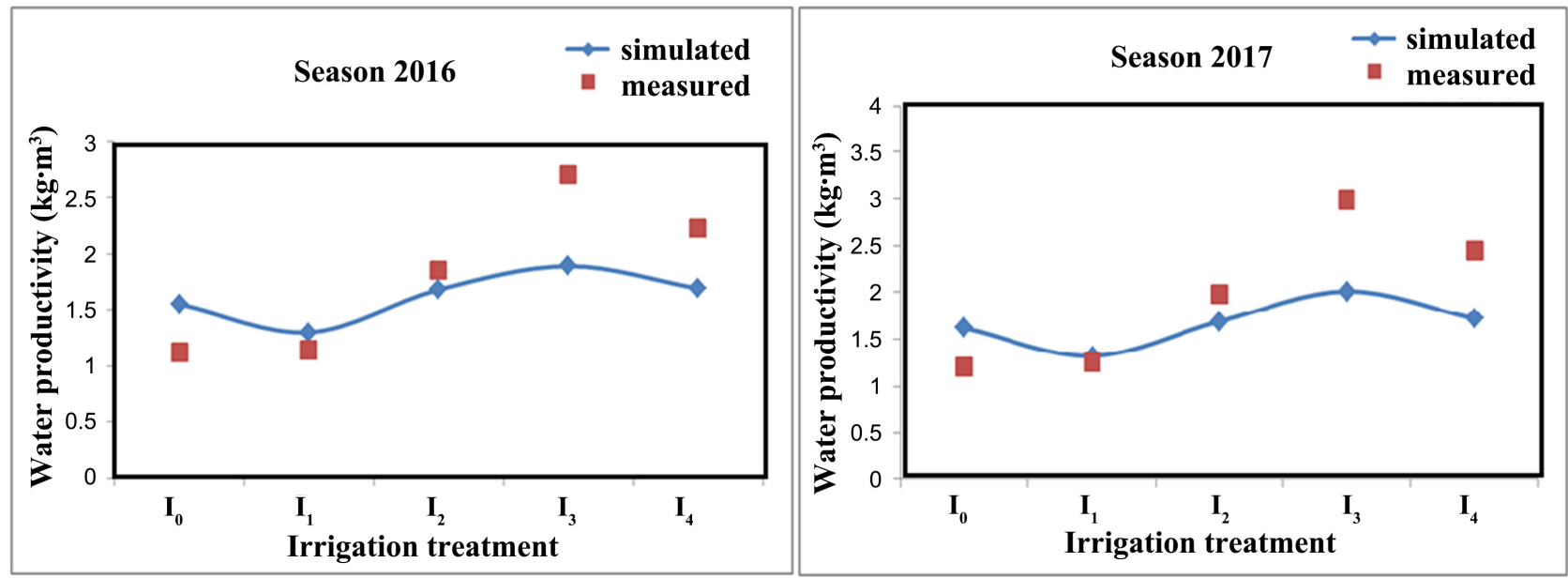

Figure 17. Simulated and measured water productivity $\left(\mathrm{kg} \cdot \mathrm{m}^{-3}\right) 2016$ and 2017 seasons.

all of which has reduced the grain yield and the biomass while the harvest index reflects the efficiency of transporting Biomass from parts of the plant towards grains and that the process of transport depends on growth factors and the lack of exposure of the plant to environmental effects, including water stress for seasons 2016 and 2017 respectively [43] [44] [45]. The furrow irrigation method treatment $\mathrm{I}_{0}$ provided sufficient moisture in the root zoon, but led to the consumption of high amounts of water due to the low efficiency of furrow irrigation method.

Figure 17 shows the presence of dispersion of the most simulated values of water productivity compared with other attributes (biomass, grain yield and harvest index). Simulation values of water productivity showed a lower estimate than the measured except for the two treatments $I_{1}$ and $I_{0}$ for the two seasons as it gave an increase in the measured compared with simulated by $14 \%$ and $38.3 \%$ in 2016 season and $-47 \%$ and $35 \%$ in 2017 season. It is clear from the above that for the least experimental data of soil and crop management, AquaCrop gave superior and excellent results for biomass, grain yield and harvest index and, to a lesser extent, to water productivity considering lack of data we need to reach this accuracy [46] [47]. Applied descriptive statistics showed that AquaCrop predicts outputs very well with appropriate accuracy and the lowest input data and satisfactory performance in the central region of Iraq and finally simplicity cannot be overlooked, however, the performance of any model in any site depends on the ideal set of parameters and validation of performance under a wide range of crops conditions.

\section{Conclusion}

This study showed that the subsurface drip irrigation with a depth of $20 \mathrm{~cm} \mathrm{I}_{3}$ was the best among other irrigation methods in terms of yield and water use efficiency, which are the two main objectives of the irrigation process. The results of this study revealed that the AquaCrop model fits to predict biomass, grain 
yield and harvest index with a high degree of reliability under different irrigation methods through the agreement between simulated and measured value for biomass, grain yield and harvest index is considered satisfactorily. Then, it is concluded that the AquaCrop model is an efficient tool to help and support decision-makers for irrigation management strategies. The results indicated that the deviation of the measured values from the simulation was very low with respect to biomass, grain yield and harvest index, ranging between (1.3\% to $2.4 \%)$ and (0.2\% to $2 \%),(2.5 \%$ to $5.5 \%),(2.1 \%$ to $4 \%)$ and ( $0.7 \%$ to $3.4 \%),(0.1 \%$ to $2.5 \%)$ for the 2016 and 2017 seasons; respectively. This indicates that AquaCrop model simulates well the conditions in which water is the limiting factor for crop production. While the deviation value of water productivity ranged between $(-30.2 \%$ to $38.3 \%),(-29.7 \%$ to $35.0 \%)$ for 2016 and 2017 seasons; respectively. Statistical procedure results of Mean Bias Error (MBE), Root Mean Square Error (RMSE), Coefficient efficiency $(E)$ and Agreement index $(d)$ confirm that AquaCrop has a high ability to simulate biomass yield, grain yield and harvest index with high accuracy

\section{Acknowledgements}

We acknowledge the support of Ministry of Water Resources, Iraq. We also thank Ecole Doctorale en Sciences et Technologie, Lebanese University.

\section{Conflicts of Interest}

The authors declare no conflicts of interest regarding the publication of this paper.

\section{References}

[1] Ewaid, S.H., Kadhum, S.A., Abed, S.A. and Salih, R.M. (2019) Development and Evaluation of Irrigation Water Quality Guide Using IWQG V. 1 Software: A Case Study of Al-Gharraf Canal, Southern Iraq. Environmental Technology \& Innovation, 13, 224-232. https://doi.org/10.1016/j.eti.2018.12.001

[2] Hirich, A., Ragab, R., Choukr-Allah, R. and Rami, A. (2014) The Effect of Deficit Irrigation with Treated Wastewater on Sweet Corn: Experimental and Modeling Study Using SALTMED Model. Irrigation Science, 32, 205-219. https://doi.org/10.1007/s00271-013-0422-0

[3] Iraqi Ministry of Planning (2017) Agricultural Sector Production Report, Water and Land, Animal and Plant Production. Iraqi Ministry of Planning.

[4] Chandra, R., Takeuchi, H. and Hasegawa, T. (2012) Methane Production from Lignocellulosic Agricultural Crop Wastes: A Review in Context to Second Generation of Biofuel Production. Renewable and Sustainable Energy Reviews, 16, 1462-1476. https://doi.org/10.1016/j.rser.2011.11.035

[5] Ibrahim, F. and de Niamey, U.A.M. (2020) Scheduling Supplementary Irrigation for Maize Production: Analysis of the Requirements for Climate Smart Farming for Rural Development. Open Access Library Journal, 7, 1-16. https://doi.org/10.4236/oalib.1106942

[6] Al-Maeini, A.H. and Nehaba, R.S. (2007) Effect of Irrigation Frequency and Plant 
Distribution on the Growth and Yield of Corn (Zea mays L). Anbar Journal of Agricultural Sciences, 5, 85-100.

[7] Erkossa, T., Awulachew, S.B. and Aster, D. (2011) Soil Fertility Effect on Water Productivity of Maize in the Upper Blue Nile Basin, Ethiopia. Agricultural Sciences, 2, 238. https://doi.org/10.4236/as.2011.23032

[8] Beyranvand, H., Farnia, A., Nakhjavan, S.H. and Shaban, M. (2013) Response of Yield and Yield Components of Maize (Zea mayz L.) to Different Bio Fertilizers. International Journal of Advanced Biological and Biomedical Research, 1, 1068-1077.

[9] Alfalahi, A.A., Al-Abodi, H.M.K., Abdul Jabbar, B.K., Muhdi, A.M. and Sulman, K.A. (2015) Scheduling Irrigation as a Water Saving Practice for Corn (Zea mays L.) Production in Iraq. International Journal of Applied Agricultural Sciences, 1, 55-59. https://doi.org/10.11648/j.ijaas.20150103.12

[10] Farooq, M., Hussain, M., Ul-Allah, S. and Siddique, K.H. (2019) Physiological and Agronomic Approaches for Improving Water-Use Efficiency in Crop Plants. Agricultural Water Management, 219, 95-108. https://doi.org/10.1016/j.agwat.2019.04.010

[11] Valipour, M., Sefidkouhi, M.A.G. and Eslamian, S. (2015) Surface Irrigation Simulation Models: A Review. International Journal of Hydrology Science and Technology, 5, 51-70. https://doi.org/10.1504/IJHST.2015.069279

[12] Mistry, P., Akil, M., Suryanarayana, T.M.V. and Parekh, F.P. (2017) Evaluation of Drip Irrigation System for Different Operating Pressures. International Journal of Advance Engineering and Research Development, 1, 63-69.

[13] Lamm, F.R., Bordovsky, J.P., Schwankl, L.J., Grabow, G.L., Enciso-Medina, J., Peters, R.T., Colaizzi, P.D., Trooien, T.P. and Porter, D.O. (2012) Subsurface Drip Irrigation: Status of the Technology in 2010. Transactions of the ASABE, 55, 483-491. https://doi.org/10.13031/2013.41387

[14] Akumaga, U., Tarhule, A. and Yusuf, A.A. (2017) Validation and Testing of the FAO AquaCrop Model under Different Levels of Nitrogen Fertilizer on Rainfed Maize in Nigeria, West Africa. Agricultural and Forest Meteorology, 232, 225-234. https://doi.org/10.1016/j.agrformet.2016.08.011

[15] de la Casa, A., Ovando, G., Bressanini, L. and Martínez, J. (2013) Aquacrop Model Calibration in Potato and Its Use to Estimate Yield Variability under Field Conditions. Atmospheric and Climate Sciences, 3, 397-407. https://doi.org/10.4236/acs.2013.33041

[16] Raja, W.R., Habib, K., and Purshotum, S. (2018) Validating the AquaCrop Model for Maize under Different Sowing Dates. Water Policy, 20, 826-840.

https://doi.org/10.2166/wp.2018.123

[17] Jin, X., Li, Z., Feng, H., Ren, Z. and Li, S. (2020) Estimation of Maize Yield by Assimilating Biomass and Canopy Cover Derived from Hyperspectral Data into the AquaCrop Model. Agricultural Water Management, 227, Article ID: 105846. https://doi.org/10.1016/j.agwat.2019.105846

[18] Heng, L.K., Hsiao, T., Evett, S., Howell, T. and Steduto, P. (2009) Validating the FAO AquaCrop Model for Irrigated and Water Deficient Field Maize. Agronomy Journal, 101, 488-498. https://doi.org/10.2134/agronj2008.0029xs

[19] Greaves, G.E. and Wang, Y.M. (2016) Assessment of FAO AquaCrop Model for Simulating Maize Growth and Productivity under Deficit Irrigation in a Tropical Environment. Water, 8, 557. https://doi.org/10.3390/w8120557

[20] Sandhu, R. and Irmak, S. (2019) Assessment of AquaCrop Model in Simulating Maize 
Canopy Cover, Soil-Water, Evapotranspiration, Yield, and Water Productivity for Different Planting Dates and Densities under Irrigated and Rainfed Conditions. Agricultural Water Management, 224, Article ID: 105753. https://doi.org/10.1016/j.agwat.2019.105753

[21] Abedinpour, M., Sarangi, A., Rajput, T.B.S., Singh, M., Pathak, H. and Ahmad, T. (2012) Performance Evaluation of AquaCrop Model for Maize Crop in a Semi-Arid Environment. Agricultural Water Management, 110, 55-66.

https://doi.org/10.1016/j.agwat.2012.04.001

[22] Khalaf, A.A. and Ham, D.S.A.D. (2019) Assessment of Aquacrop Model in Prediction Maize Hybirds Yield by Simulation Production under Deficit Irrigation. Journal of Duhok University, 22, 7-23. https://doi.org/10.26682/avuod.2019.22.1.2

[23] Shah, A.H., Khan, M.F. and Khaliq, A. (2003) Genetic Characterization of Some Maize (Zea mays L.) Varieties Using SDS-PAGE. Asian Journal of Plant Sciences, 2, 11881191. https://doi.org/10.3923/ajps.2003.1188.1191

[24] Zhao, Y., Li, F., Wang, Y. and Jiang, R. (2020) Evaluating the Effect of Groundwater Table on Summer Maize Growth Using the AquaCrop Model. Environmental Modeling \& Assessment, 25, 343-353. https://doi.org/10.1007/s10666-019-09680-y

[25] Wolka, K., Biazin, B., Martinsen, V. and Mulder, J. (2021) Soil and Water Conservation Management on Hill Slopes in Southwest Ethiopia. II. Modeling Effects of Soil Bunds on Surface Runoff and Maize Yield Using AquaCrop. Journal of Environmental Management, 296, Article ID: 113187. https://doi.org/10.1016/j.jenvman.2021.113187

[26] Ran, H., Kang, S., Li, F., Du, T., Tong, L., Li, S., Zhang, X., et al. (2018) Parameterization of the AquaCrop Model for Full and Deficit Irrigated Maize for Seed Production in Arid Northwest China. Agricultural Water Management, 203, 438-450. https://doi.org/10.1016/j.agwat.2018.01.030

[27] He, Q., Li, S., Hu, D., Wang, Y. and Cong, X. (2020) Performance Assessment of the AquaCrop Model for Film-Mulched Maize with Full Drip Irrigation in Northwest China. Irrigation Science, 39, 277-292. https://doi.org/10.1007/s00271-020-00705-Z

[28] SAS, J. (2012) Statistical Analysis System. v. 10.0. 2, Cary, North Carolina.

[29] Ibrahim, H.I. and Juma, S.S. (2021) Effect of Mineral Fertilization and Humic Acids on Availability of NPK in Soil and Maize Growth. Annals of the Romanian Society for Cell Biology, 25, 11414-11418.

[30] Vermeiren, L. and Jobling, G.A. (1980) Localized Irrigation: Design, Installation, Operation, Evaluation. FAO, Rome.

[31] Kovda, V.A., Berg, C.V.D. and Hagan, R.M. (1973) Irrigation, Drainage and Salinity: An International Source Book. FAO, Rome.

[32] Allen, R.G., Pereira, L.S., Raes, D. and Smith, M. (1998) Crop Evapotranspiration Guidelines for Computing Crop Water Requirements. FAO Irrigation and Drainage Paper No. 56, FAO, Rome.

[33] Howell, C.R. (2003) Mechanisms Employed by Trichoderma Species in the Biological Control of Plant Diseases: The History and Evolution of Current Concepts. Plant disease, 87, 4-10. https://doi.org/10.1094/PDIS.2003.87.1.4

[34] Katerji, N., Campi, P. and Mastrorilli, M. (2013) Productivity, Evapotranspiration, and Water Use Efficiency of Corn and Tomato Crops Simulated by AquaCrop under Contrasting Water Stress Conditions in the Mediterranean Region. Agricultural Water Management, 130, 14-26. https://doi.org/10.1016/j.agwat.2013.08.005

[35] Willmott, C.J. (1982) Some Comments on the Evaluation of Model Performance. Bul- 
letin of the American Meteorological Society, 63, 1309-1313. https://doi.org/10.1175/1520-0477(1982)063<1309:SCOTEO >2.0.CO;2

[36] Hsiao, T.C., Heng, L., Steduto, P., Rojas-Lara, B., Raes, D. and Fereres, E. (2009) AquaCrop-The FAO Crop Model to Simulate Yield Response to Water: III. Parameterization and Testing for Maize. Agronomy Journal, 101, 448-459.

https://doi.org/10.2134/agronj2008.0218s

[37] Steduto, P., Hsiao, T.C., Raes, D. and Fereres, E. (2009) AquaCrop-The FAO Crop Model to Simulate Yield Response to Water: I. Concepts and Underlying Principles. Agronomy Journal, 101, 426-437. https://doi.org/10.2134/agronj2008.0139s

[38] Mebane, V.J., Day, R.L., Hamlett, J.M., Watson, J.E. and Roth, G.W. (2013) Validating the FAO AquaCrop Model for Rainfed Maize in Pennsylvania. Agronomy Journal, 105, 419-427. https://doi.org/10.2134/agronj2012.0337

[39] Wu, D., Xu, X., Chen, Y., Shao, H., Sokolowski, E. and Mi, G. (2019) Effect of Different Drip Fertigation Methods on Maize Yield, Nutrient and Water Productivity in Two-Soils in Northeast China. Agricultural Water Management, 213, 200-211. https://doi.org/10.1016/j.agwat.2018.10.018

[40] Mansour, H.A., Hu, J., Pibars, S., Bao, H. F. and Liang, C. (2019) Effect of Pipes Installation by Modified Machine for Subsurface Drip Irrigation System on Maize Crop Yield Costs. Agricultural Engineering International: CIGR Journal, 21, 98-107.

[41] Wang, D., Li, G., Mo, Y., Zhang, D., Xu, X., Wilkerson, C.J. and Hoogenboom, G. (2021) Evaluation of Subsurface, Mulched and Non-Mulched Surface Drip Irrigation for Maize Production and Economic Benefits in Northeast CHINA. Irrigation Science, 39, 159-171. https://doi.org/10.1007/s00271-020-00692-1

[42] Stricevic, R., Cosic, M., Djurovic, N., Pejic, B. and Maksimovic, L. (2011) Assessment of the FAO AquaCrop Model in the Simulation of Rainfed and Supplementally Irrigated Maize, Sugar Beet and Sunflower. Agricultural Water Management, 98, 16151621. https://doi.org/10.1016/j.agwat.2011.05.011

[43] Babel, M.S., Deb, P. and Soni, P. (2019) Performance Evaluation of AquaCrop and DSSAT-CERES for Maize under Different Irrigation and Manure Application Rates in the Himalayan Region of India. Agricultural Research, 8, 207-217. https://doi.org/10.1007/s40003-018-0366-y

[44] Anzoua, K.G., Junichi, K., Toshihiro, H., Kazuto, I. and Yutaka, J. (2010) Genetic Improvements for High Yield and Low Soil Nitrogen Tolerance in Rice (Oryza sativa L.) under a Cold Environment. Field Crops Research, 116, 38-45. https://doi.org/10.1016/j.fcr.2009.11.006

[45] Guo, D., Zhao, R., Xing, X. and Ma, X. (2020) Global Sensitivity and Uncertainty Analysis of the AquaCrop Model for Maize under Different Irrigation and Fertilizer Management Conditions. Archives of Agronomy and Soil Science, 66, 1115-1133. https://doi.org/10.1080/03650340.2019.1657845

[46] Paredes, P., de Melo-Abreu, J.P., Alves, I. and Pereira, L.S. (2014) Assessing the Performance of the FAO AquaCrop Model to Estimate Maize Yields and Water Use under Full and Deficit Irrigation with Focus on Model Parameterization. Agricultural Water Management, 144, 81-97. https://doi.org/10.1016/j.agwat.2014.06.002

[47] Zhu, X., Xu, K., Liu, Y., Guo, R. and Chen, L. (2021) Assessing the Vulnerability and Risk of Maize to Drought in China Based on the AquaCrop Model. Agricultural Systems, 189, Article ID: 103040. https://doi.org/10.1016/j.agsy.2020.103040 